\title{
GEOSPATIAL TECHNOLOGY APPLICATION IN LOCAL LEVEL LAND USE PLANNING IN NEPAL
}

\author{
Umesh K Mandal ${ }^{1, *}$ and Kabita Kumari ${ }^{2}$ \\ ${ }^{1}$ Central Department of Geography, Tribhuvan University, Kathmandu, Nepal, umesh_jee@ hotmail.com \\ ${ }^{2}$ Bernhardt College, Balkhu, Kathmandu, and Nepal,kabitamandal679@yahoo.com
}

Commission III, WG III/10

KEY WORDS: Land Use Planning, National Land Use Policy, National Land Use Project, Geospatial technology

ABSTRACT:

Even though planning process particularly economic development plan and its implementation in Nepal has been initiated with first five-year plan in 1952/54, land resource planning was overshadowed and only regional level data base on land use, land system and land capability were produced by Land Resource Mapping Project in 1983/84 and made available for planners and decision makers for sectoral planning in regional scale. During past, different policies and national planning efforts were made for balanced use of country's existing natural resources but Nepal has not practiced land-use planning for the country as a whole at local level. It is initiated only after ninth five year plan (1997-2002) with the establishment of National Land Use Project under Ministry of Land Reform and Management and formulation of National Land Use Policy 2013 and its revision in 2015 after devastating earthquake. Land use council, Land use technical committee, District level land use monitoring committee and VDC/municipality level land use committee are institutional set ups for implementing planning works done by National Land Use Project at district and local levels. Resource maps produced by different international agency associated with India, Canada, USA, Japan and Finland were worked as basis for formulation of local level land use plans. Presently National Land Use Project (NLUP) has prepared land resources maps, geo-database and reports covering almost half of total VDCs of the country moreover in Terai region. Seven components of land resources management required for local level land use planning are present land use map, soil map, land capability map, hazard risk map, land use zoning map, cadastral superimpose on land use zoning map along with its geo-database and report except VDC profile. In first time, geospatial technology-RS, GIS and GPS were extensively applied in preparation of all these resource maps and creation of their geo-database for local level land use planning.

\section{INTRODUCTION}

Planning process in Nepal has been initiated with the first development plan in 1956 after few years of downfall of Rana Rule, aiming of improving the wellbeing of people focusing on economic development of Nepal (Srivastava, 2008) without spatial consideration. Regional approach as a spatial dimension was introduced in national development plan only in fourthFive Year Plan(1970-1975) after realizing the fact of spatial disparity increased in socio-economic development (Gurung, 2005). It was not continued till Ninth Five-Year Plan because of sectoral coordination, lack of infrastructure development and skilled manpower integrating north-south development corridor/axis.

The mapping history of land resources in the country was started with the preparation of first topographical base map at scale of 1" = 1 mile during 1950-60 with the co-operation of the Government of India and it produced a total of 266 maps sheets covering the whole country. Lack of geospatial technology application, these maps was suffered as positional inaccuracies, outdated, small scale, non-metric units of measurements and different projection systems and parameters used than the present system. In spite of drawbacks, these first topographical maps were used for a long period of time in all development and administrative activities of Nepal.

The application of satellite image was initiated first time in Nepal only after 1977, with the assistance of Canadian Government; Land Resource Mapping Project (LRMP) was launched. Under this project different thematic maps like land capability, land System, Land Utilization in the scale of 1:50 000 were prepared covering entire geographical areas of country along with Geological map, Climatological maps of
Nepal based on existing $1 "=1$ mile and aerial photographs were also taken in 1978. In the preparation of these maps, Landsat imageries were used for identification of land types, land unit and land use land cover types. Regional level landscape data were made available for planners, decision makers and academicians through LRMP maps.

In 1989, with the assistance of Japanese Government, Topographical base maps of Lumbini Zone were prepared consisting of 81 map sheets in the scale of 1:25 000. With the grant assistance of Finnish government, topographical mapping of remaining zones of eastern and central development regions were started in 1991. Accordingly a new series of topographical base maps at 1:25000 scale for terai plains and mid- mountain regions and 1:50 000 for the rest area was completed in 2002 . In the first phase of the project a total of 294 map sheets was completed in 1996 and in the second phase of the project a total of 255 sheets at a scale of 1:25000 was completed in 1999 and in the third phase a total of 76 map sheets in the scale of 1:50 000 was completed in 2001. Including 81 maps sheets of Lumbini zone, a total of 706 topographical map sheets are available. These maps were also not prepared under the application of geospatial technology but based on previous LRMP maps and aerial photographs at the same regional level rather than local level.

Regional scale maps were not sufficient for proper management of land and its resources for fulfilling the basic needs of growing population- food, fiber \& shelter. In such situation, land as the primary natural resource should be central for any development activity of the country in terms of its sustainable utilization playing a vital role for the prosperity of the country. Therefore, proper land management is a prime importance for balancing all round development in the country 
otherwise managing even basic needs such as food, clothes and shelter for the people of future generation will really became challenging task. It is mentioned in the land use policy of the Ninth Five Year Plan (1997-2002) their emphasis shall be given to classify the arable land by identifying capacity of productivity of land. In order to fulfill this policy, national land use project was established in 2000. A land use council was constituted as per the article 51 Cha of land related act 2021 (5th amendment) for implementing land use program. The project is following the policy, guidelines and implements the program as specified by the land use council. In the Tenth Five Year Plan (2002-2007), implementation of land use program was included. So, the project initiated its work to update existing land resources maps-land use, soil, land capability, risk, land use zone, cadastral superimpose on land use zone for local level planning unit like village / municipalities development committees using geospatial technology.

\section{MATERIALS AND METHODS}

\subsection{Preparation of Land Resource Map and Geo-database}

Land resource map consists of land use, soil, land capability, risk, land use zone and cadastral superimpose in land use zoning map. Satellite image, GIS and differential GPS as the geospatial technologies were used in processing of satellite data and other spatial data like topographical and LRMP. The detailed methodology of its preparation was given below thematically as sub-headings.

\subsubsection{Land use}

High resolution commercial satellite images-Geo-Eye and World-View having pan of $0.46 \mathrm{~m}$ and mss of $1.85 \mathrm{~m}$ spatial resolution with dynamic range of 11 bits radiometric resolution.was first time applied in preparation of updating land use map in the country. Topographical maps were used for planning process of GCPs collection with DGPS survey and also used for feature extraction of dataset such as drainage network, administration boundary, location name, etc. DEM which is used for ortho-rectification of satellite images and creation of DEM based slope, aspect, relief, and hill shade using terrain analysis, was generated from digital topographical map of $20 \mathrm{~m}$ contour interval using ANUDEM algorithm with topoto raster tool. For the geometric correction of optical images, there are two mathematical approaches- rigorous sensor model (RSM), which is parametric based on satellite orbital parameters, is used in direct geo-referencing techniques and rational polynomial co-efficient (RPCs), which is nonparametric or generic and advanced form of RPF model. The RPC model has universally used for interior and exterior orientation of each satellite images for transformation of image column and row values of the original image to object ground co-ordinates using third order polynomials for numerator and denominator of at least 80 coefficients. Resolution merge or image fusion as a techniques of pan sharpening was used to create a high resolution multispectral data by the fusion process of high resolution panchromatic data with lower resolution multispectral data. Rectified satellite image was classified using the supervised classification method adopting the maximum likelihood classifier algorithm. Error matrix was generated to see the level of classification accuracy from training samples collected during the field visit. Visual image interpretation was also performed using interpretation keys and classified feature were verified in the field. Seven hierarchy classification of land use classes mentioned in Land Use Policy 2015 were identified in processed image.

\subsubsection{Soil}

Soil survey methodology adopted for the local level planning comprises of three activities- desk study, soil survey and soil laboratory analysis. The desk study comprised of the study of the existing maps and reports- LRMP land system \& report, topographic map, geological map and data- related to soil, geology, terrain/DEM,high resolution satellite image-pan and MSS( world view-2, Geo-Eye-1 \& IKONOS) as well as other aspects relate to the study area. These layers were integrated by GIS analysis, digital photogrammetry and remote sensing techniques and GPS enabling digital modeling of the landscape in micro-scale to effectively delineate each soil mapping/ landform unit and its association with the soil. These land units were taken as soil mapping units for detailed soil survey. Anaglyph using satellite image and digital terrain model were developed and used for interactively $3 \mathrm{D}$ perspective visualizing the terrain. High resolution satellite imagery Geo-Eye \& World View having $2 \mathrm{~m}$ spatial resolution in MSS was used for visualization of the terrain landform units in order to perceive the soil variation in characteristics. The soil survey was carried out by digging standard soil pits size of $1 \mathrm{~m}^{3}$ in each identified representative soil mapping unit. A vertical cross-section of the soil pit profile was studied for each layer by texture, colour, structure, consistency, presence of pores, roots and insects burrows/worm casts, stoniness, compaction, clay etc. In addition, physiographic, landform, parent material, drainage, vegetation and land use of each site and surrounding were studied. All these information related to site characteristics, general information of soil and detailed description of each individual horizon were recorded in standard description form developed by National Land Use Project (NLUP).

Soil laboratory analysis included the testing of chemical characteristics of individual soil samples representing top horizon (A) at different soil test laboratories- regional soil test laboratory of Hetauda and Pokhara, ATC and NEST as private. Routine test like $\mathrm{pH}$, texture, organic matter, total nitrogen, available phosphorous and potassium were determined by using methods, 1:2.5 Water Suspension, Hydrometer \& Texture Classification of USDA, Walkley and Black, Microjeldahl, Olson \& Bray and Sulphuric Acid Extraction by colorimeter respectively for plant nutrition/fertility assessment.

\subsubsection{Land Capability}

Local level land capability classification was done using geospatial technology viz. GIS, GPS and RS. Spatial analysis in GIS was performed to integrate soil and terrain parameters to designate capability classes, arability classes, deficiency subtype and sub-type unit. A multi-criteria evaluation rule was developed to classify soil mapping units based on soil parameter, fertility, erosion susceptibility, terrain constraints and surface drainage (wetness). Land capability evaluation criteria comprised of soil fertility, topography, erosion susceptibility and surface drainage. Soil fertility evaluation is based on ratings soil parameters (NARC 2013) related to topsoil of rooting depth, workability (soil texture), soil drainage (permeability), alkalinity and acidity, content of organic matters, total nitrogen, available phosphorus, and available potassium. Similarly, topographic criteria are related to the steepness of the terrain slopes and surface dissection limiting the sustainable use of land and it requires careful management 
with terracing and maintaining vegetation cover to mitigate soil degradation.

Erosion susceptibility criteria are based on susceptibility rating of different types of erosion like rill, sheet and gully affecting the potential of soil loss due to erosion. Likewise surface drainage (wetness) criteria pertain to the drainage condition of surface in terms of frequent flooding, water logging and high water table as the problems affecting the productivity and use of land.

Finally land capability classification is performed evaluating all parameters mentioned above using weighted composite score based on multi-criteria analysis. Weighted composite score (WCS) is a systematic procedure for developing factor weights required for preparing capability map. The weights assigned to different factors were obtained by subjective to expert judgment. The larger the weight, the more important is the criterion in the overall capability class as described by Malczewski (2000). In developing the weights, an individual factor was ranked as low, medium, and high and very high weight were assigned as 1, 2, 3 and 4 respectively based on 4point scale. Weighted Composite Score (WCS) was employed based on parameter weight and individual weighted value as 4 , 3,2 and 1 corresponding to very high, high, medium and low rank of concerned factor respectively. The final value of weighted composite score (WCS) for each soil mapping unit was calculated by summing all individual factors value obtained by multiplying individual factor weight rank value with their corresponding weight of parameters (Grose, 1999; Store and Kangas, 2001).

\subsubsection{Risk}

Even though local level land use planning in Nepal has been initiated from 2008, risk assessment was added only after occurrence of devastating earthquake in Sep 25, 2015 in order to have safe land use zoning process. Potential different types of risk such as fire, flood, landslide, seismic, industrial and their proximity of occurrences, risk can be hierarchically classified as different level: such as high, medium and low.

Fire risk was studied though detailed field investigation regarding to community forest, settlement status, industries and petro-chemical station and the recording of past firing condition and through the extensive consultation with government representatives at various levels, experts and professionals, local communities and industrial stockholders.

Flood risk and vulnerability mapping was conducted integrating different approaches- geographic using GIS and RS, modeling of rainfall-runoff processes using US Army Corps of Engineers Hydrological Engineering Corporation's River System Analysis (HEC-RAS) model; and social flood hazard mapping based on local people's perceptions and experiences. Multi-criteria weighted scoring index was used to assess landslide hazard assessment by identifying spatial distribution of landslides in high resolution satellite image. The analyzed data has been taken from the secondary sources. Maps of epicentre of the earthquake in Nepal himalaya, and probabilistic seismic hazard assessment map of the Nepal Himalaya were used to assess seismic hazard by using empirical method rather than simplest method and dynamic analysis method due to unavailability of parameters-design input motion, the soil structure model and the properties of the rock materials. Industrial risk was also assessed by detailed field investigation and consultation of stakeholders and proximity neighborhood analysis to be mapped of areas potentially polluted. Geo-spatial technology along with high resolution satellite images, household survey, group discussions, field observation and published and unpublished documents were used in all types of risk assessment.

\subsubsection{Land Use Zoning}

Local level land use zoning is performed mainly by using geospatial technology based spatial analysis and multiple criteria analysis on several available data sets-present land use,socioeconomic, land capability and multi-hazards considering the specified zones mentioned in specification guided by National Land Use Policy-2015(GON/MLRM 2015). The guiding principles of land use zoning are- necessity of land, its composition, capability, current use and appropriateness.

\subsubsection{Cadastral superimpose on land use zoning}

Cadastral maps for entire country were prepared from systematic cadastral survey conducted in 1967 using plane table leveling at different scales (Bhumichitra, 2000). Department of Land Information and Archive (DoLIA) started to keep and update land parcel records by digitization from 1993 after its establishment (Bhandari 2017). The missing cadastral maps which were not updated by DoLIA, were scanned at $300 \mathrm{dpi}$ and geogreferenced at national coordinate system (MUTM). These cadastral maps were superimposed in land use zoning maps to quantify the number of land parcels and their spatial extent by per land use zones specified for local level planning of resources at village/municipality development committee level.

\subsection{Preparation of Bio-physical and Socio-economic Profile}

Socio-economic profile including bio-physical condition for local level planning unit was prepared by collecting information on physical, economic, social, historical, and environmental aspects, and land resource, agriculture, forest, livestock etc. together with infrastructures, services and population growth and migration through check-list, focus group discussion (FGD, key informants information (KII) and recorded documents in local units required for the land use zoning.

\section{RESULTS AND DISCUSSIONS}

\subsection{Present Land Use Classification}

For the local level land use planning in Nepal, present land use was classified as seven-tier hierarchical scheme mentioned in National Land Use Policy-2015 and it had further sub-classes employing hierarchical classification basis upto seven levels. The level-1 categories of the land use consisting of eleven classes were as Agriculture (AGR), Forest (FOR), Residential (RES), Commercial (COM), Industrial (IND), Public Service (PUB), Mine and Minerals (MIN), Cultural and Archeological (CULARCH), Riverine and Lake Area (HYD), Excavation Area (EXC) and Other (OTH). Agricultural land use was further sub-categorized in level-2, level-3, level-4, level-5 and level-6 based on physiographic location, irrigation or moisture condition, micro-relief location, crop rotation or cropping pattern and cropping intensity respectively. Similarly, forest land use was further sub-categorized upto seven hierarchical levels representing climatic vegetation zone at level-2, cover type at level-3, dominant species types at level-4, crown density types at level-5, maturity classes at level-6 and ownership or use right at level-7. Likewise, residential land use has further four levels of hierarchical classification characterizing house 
density at level-2, historical development of settlement at level3 and purposes of house or building use. In the same way, commercial land use was also sub-categorized upto four levels indicating nature of functions performed at level-2, sectors providing services at level-3 and individual functions at level-4. Industrial land use was sub-classified only upto second level representing nature and size of manufacturing products. Public service land use was also further sub-classified upto four levels based on the criteria of types of services provided at level-2, individual services at level-3 and designated name at level-4. Mines and mineral land use was also sub-categorized upto five levels representing metallic/non-metalic/material type at level 2 , individual element at level-3, license/non-license at level-4 and operating condition at level-5. Cultural-archeological and lake- riverine land use were also sub-categorized at only second-level based on its typology. Excavation land use were sub-categorized upto three levels indicating nature of material at level-2 and licensing condition at level-3.

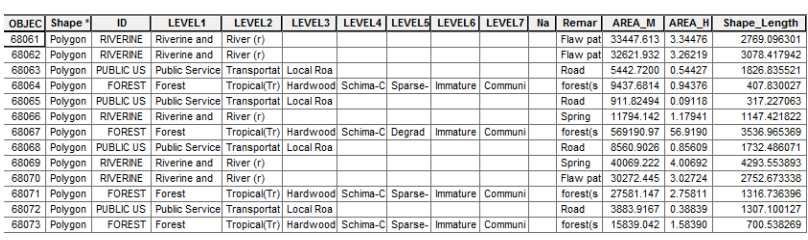

Table 1: Geo-database of present land use classification of Aanbu Khaireni rural municipality, Tanahun district, Nepal.

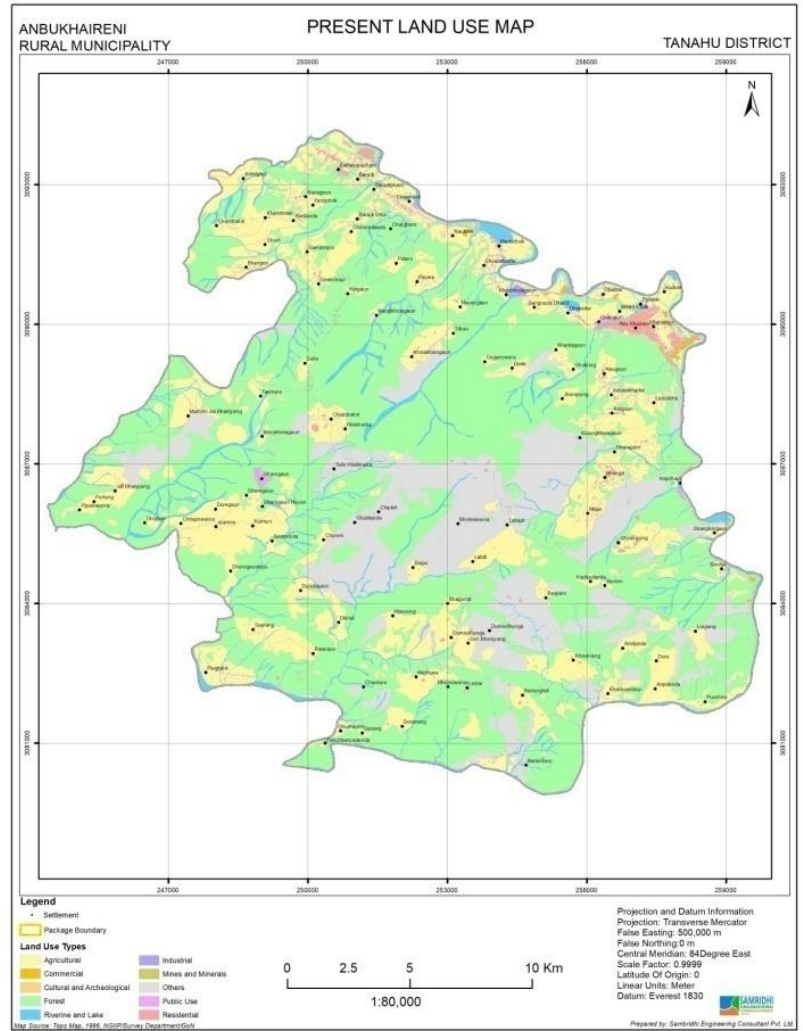

Figure 1: Present land use types of Aanbu Khaireni, rural municipality of Tanahun district, Nepal.

Other land use was sub-classified as grass land, bamboo and orchard at level-2 and their climatic vegetation zone type at level-3 and specific species at level-4. As an illustration, geodatabase of present land use classification of Aanbu Khaireni, Rural Municipality, and Tanahun District was depicted in Table
1 and its present land use types representing Level-1 was shown in Figure 1. Striking point is that there are seven land use types prescribed in National Land Use Policy-2013 where as it is extended upto eleven classes and their sub-classes in revised policy-2015.

\subsection{Soil Classification}

For the local level fertility assessment in Nepal, soil classification was performed based on USDA soil classification (USDA, 2010) scheme as mentioned in National Land Use Policy-2015. Physical and chemical characteristics of soil were analyzed based on USDA soil manual and guidelines (USDA 2017). Ranking status of physical and chemical parameters of soil with respect to required for crops were analyzed using guidelines developed (NARC 2013). Soils were classified based on order, sub-order, great group, sub-group, family and series based on soil taxonomy. Routine test of $\mathrm{pH}$, organic matter, total nitrogen, available potassium \& phosphorous and texture classes of epipodon were analyzed and linked to the fertility status of agriculture crops required. As an illustration, geodatabase of soil classification of Aanbu Khaireni, Rural Municipality of Tanahun District was depicted in Table 2 and its mapping at sub-group level was shown in Figure 2.

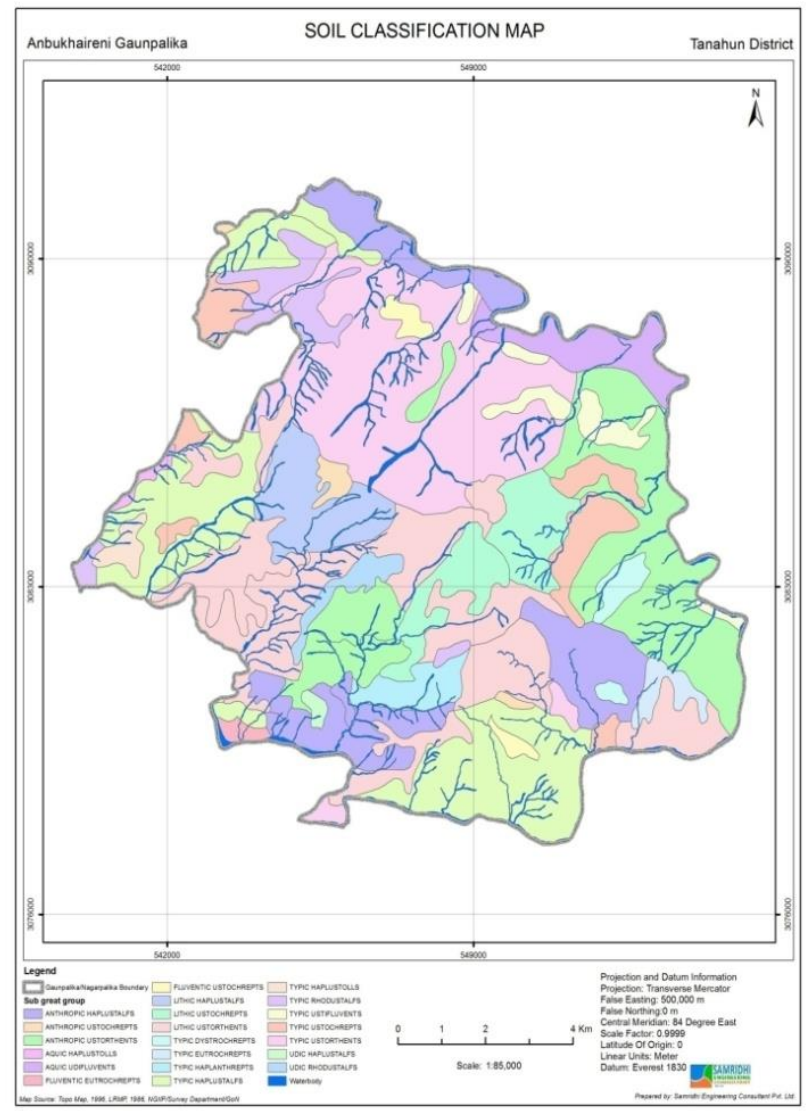

Figure 2: Soil classification of Aanbu Khaireni, rural municipality of Tanahun district, Nepal.

Surface interpolation maps of primary nutrients like soil reaction, organic matter, total nitrogen, available potassium and phosphorous were prepared using geo-statistical technique in geo-spatial domain. Soil fertility assessment was performed from the information of primary nutrients derived from top-soil. The information viz. cation exchange capacity (CEC) and base 
saturation of sub-soil are found essential for comprehensive study of soil taxonomy.

\begin{tabular}{|c|c|c|c|c|c|}
\hline ORDER & $\begin{array}{l}\text { SUB- } \\
\text { ORDE } \\
\text { R } \\
\end{array}$ & GROUP & SUB-GROUP & FAMILY $_{-}$ & $\begin{array}{l}\text { SER } \\
\text { IES } \\
\text { SSC } \\
\end{array}$ \\
\hline $\begin{array}{l}\text { INCEPTI } \\
\text { SOLS }\end{array}$ & $\begin{array}{l}\text { OCHR } \\
\text { EPTS }\end{array}$ & $\begin{array}{l}\text { USTOCH } \\
\text { REPTS }\end{array}$ & $\begin{array}{l}\text { FLUVENTIC } \\
\text { USTOCHREPTS }\end{array}$ & $\begin{array}{l}\text { SANDY LOAM } \\
\text { HYPERTHERMIC } \\
\text { FLUVENTIC USTOCHREPTS }\end{array}$ & Oc1 \\
\hline $\begin{array}{l}\text { ENTISOL } \\
\mathrm{S}\end{array}$ & $\begin{array}{l}\text { ORTH } \\
\text { ENTS }\end{array}$ & $\begin{array}{l}\text { USTORT } \\
\text { HENTS }\end{array}$ & $\begin{array}{l}\text { ANTHROPIC } \\
\text { USTORTHENTS }\end{array}$ & $\begin{array}{l}\text { SANDY LOAM } \\
\text { HYPERTHERMIC } \\
\text { ANTHROPIC USTORTHENTS } \\
\end{array}$ & Or3 \\
\hline $\begin{array}{l}\text { ENTISOL } \\
\text { S }\end{array}$ & $\begin{array}{l}\text { FLUVE } \\
\text { NTS } \\
\end{array}$ & $\begin{array}{l}\text { USTIFLU } \\
\text { VENTS }\end{array}$ & $\begin{array}{l}\text { TYPIC } \\
\text { USTIFLUVENTS }\end{array}$ & $\begin{array}{l}\text { SANDY LOAM } \\
\text { HYPERTHERMIC TYPIC } \\
\text { USTIFLUVENTS } \\
\end{array}$ & Fl1 \\
\hline $\begin{array}{l}\text { INCEPTI } \\
\text { SOLS }\end{array}$ & $\begin{array}{l}\text { OCHR } \\
\text { EPTS }\end{array}$ & $\begin{array}{l}\text { USTOCH } \\
\text { REPTS }\end{array}$ & $\begin{array}{l}\text { ANTHROPIC } \\
\text { USTOCHREPTS }\end{array}$ & $\begin{array}{l}\text { SANDY LOAM THERMIC } \\
\text { ANTHROPIC USTOCHREPTS }\end{array}$ & Oc1 \\
\hline $\begin{array}{l}\text { ENTISOL } \\
\text { S }\end{array}$ & $\begin{array}{l}\text { ORTH } \\
\text { ENTS }\end{array}$ & $\begin{array}{l}\text { USTORT } \\
\text { HENTS }\end{array}$ & $\begin{array}{l}\text { LITHIC } \\
\text { USTORTHENTS }\end{array}$ & $\begin{array}{l}\text { LOAM THERMIC LITHIC } \\
\text { USTORTHENTS }\end{array}$ & Or3 \\
\hline $\begin{array}{l}\text { MOLLIS } \\
\text { OLS }\end{array}$ & $\begin{array}{l}\text { USTOL } \\
\text { LS }\end{array}$ & $\begin{array}{l}\text { HAPLUS } \\
\text { TOLLS }\end{array}$ & $\begin{array}{l}\text { TYPIC } \\
\text { HAPLUSTOLLS }\end{array}$ & $\begin{array}{l}\text { LOAM HYPERTHERMIC } \\
\text { TYPIC HAPLUSTOLLS }\end{array}$ & Us5 \\
\hline $\begin{array}{l}\text { INCEPTI } \\
\text { SOLS }\end{array}$ & $\begin{array}{l}\text { OCHR } \\
\text { EPTS }\end{array}$ & $\begin{array}{l}\text { USTOCH } \\
\text { REPTS }\end{array}$ & $\begin{array}{l}\text { TYPIC } \\
\text { USTOCHREPTS }\end{array}$ & $\begin{array}{l}\text { SANDY LOAM } \\
\text { HYPERTHERMIC TYPIC } \\
\text { USTOCHREPTS } \\
\end{array}$ & $\mathrm{Oc1}$ \\
\hline $\begin{array}{l}\text { ALFISOL } \\
\mathrm{S}\end{array}$ & $\begin{array}{l}\text { USTAL } \\
\text { FS }\end{array}$ & $\begin{array}{l}\text { RHODUS } \\
\text { TALFS }\end{array}$ & $\begin{array}{l}\text { UDIC } \\
\text { RHODUSTALFS }\end{array}$ & $\begin{array}{l}\text { SANDY LOAM THERMIC } \\
\text { UDIC RHODUSTALFS }\end{array}$ & Us6 \\
\hline $\begin{array}{l}\text { ALFISOL } \\
\text { S }\end{array}$ & $\begin{array}{l}\text { USTAL } \\
\text { FS }\end{array}$ & $\begin{array}{l}\text { RHODUS } \\
\text { TALFS }\end{array}$ & $\begin{array}{l}\text { TYPIC } \\
\text { RHODUSTALFS }\end{array}$ & $\begin{array}{l}\text { LOAM THERMIC TYPIC } \\
\text { RHODUSTALFS }\end{array}$ & Us6 \\
\hline $\begin{array}{l}\text { INCEPTI } \\
\text { SOLS }\end{array}$ & $\begin{array}{l}\text { OCHR } \\
\text { EPTS }\end{array}$ & $\begin{array}{l}\text { DYSTRO } \\
\text { CHREPT } \\
\text { S } \\
\end{array}$ & $\begin{array}{l}\text { TYPIC } \\
\text { DYSTROCHREP } \\
\text { TS }\end{array}$ & $\begin{array}{l}\text { SANDY LOAM THERMIC } \\
\text { TYPIC DYSTROCHREPTS }\end{array}$ & Oc1 \\
\hline
\end{tabular}

Table 2: Geo-database of soil classification of Aanbu Khaireni rural municipality, Tanahun district, Nepal.

\subsection{Land Capability Classification}

Land capability classification for local level land use planning in Nepal was performed based on principles of USDA land capability classification (Grose, 1999) and guidelines of LRMP land capability report (LRMP, 1986) considering criteria of soil fertility, topographic, erosion and surface drainage along with specific management limitation pertaining to the soil for sustainable agricultural uses in particular soil mapping unit.

\begin{tabular}{|l|l|l|l|l|l|l|}
\hline $\begin{array}{l}\text { Clas } \\
\text { ses }\end{array}$ & $\begin{array}{l}\text { sub } \\
\text { divis } \\
\text { ions }\end{array}$ & $\begin{array}{l}\text { Moistu } \\
\text { re } \\
\text { Regim } \\
\text { e }\end{array}$ & $\begin{array}{l}\text { Crop } \\
\text { suitabil } \\
\text { ity/ara } \\
\text { bility }\end{array}$ & $\begin{array}{l}\text { Capabil } \\
\text { ity } \\
\text { Classes }\end{array}$ & $\begin{array}{l}\text { Area } \\
\text { (ha) }\end{array}$ & $\begin{array}{l}\text { \% Area } \\
\text { covera } \\
\text { ge }\end{array}$ \\
\hline II & A & u & 2st & $\begin{array}{l}\text { IIAu/2s } \\
\text { t }\end{array}$ & 716.27 & 5.6 \\
\hline III & A & u & & IIIAu & 12.04 & 0.09 \\
\hline III & B & h & & IIIBh & 0.14 & 0.001 \\
\hline IV & A & u & & IVAu & 2150.16 & 16.8 \\
\hline IV & B & h & & IVBh & 213.2 & 1.67 \\
\hline Non arable (Forest and buildings) & & 8990.37 & 70.24 \\
\hline \multicolumn{7}{|l}{ Water body } \\
\multicolumn{7}{|l}{ Total } \\
\hline \multicolumn{7}{|l}{} \\
\hline
\end{tabular}

Table 3: Land capability classification of Aanbu Khaireni rural municipality, Tanahun district, Nepal.

Capability classification was adopted three hierarchical levelsclasses indicating the general degree of limitations to use; subclasses representing the dominant kind of limitation based on soil, topographic, erosion and wetness and unit differentiates between lands with similar management and conservation requirements as well as productivity characteristics.

The land capability classes in Nepal comprise seven classes ranked in order of increasing degree of limitation and in decreasing order of adaptability for agricultural use. Class- I land is identified as the best suited land producing wider range of crops and pastures at higher levels of production with lower costs and/or with less management requirements and/or less risk of damage to land compared to any other classes of land. Class- II is superior to Classes 3 to 7 but less superior to Class I, and so on. Class I to III, are considered as capable of supporting cropping activities on sustainable basis. Class IV is suited for forestry. Class V is suited for grazing pastures and fodder collection. Class VI has severe limitation and considered fragile and suitable for rough seasonal grazing only. Class VII land comprises of rock and snow cover with severe management limitations which cannot be corrected. As an example, land capability classification of Aanbu Khaireni, Rural Municipality of Tanahun District was depicted in Table 3 and its mapping was shown in Figure 3.

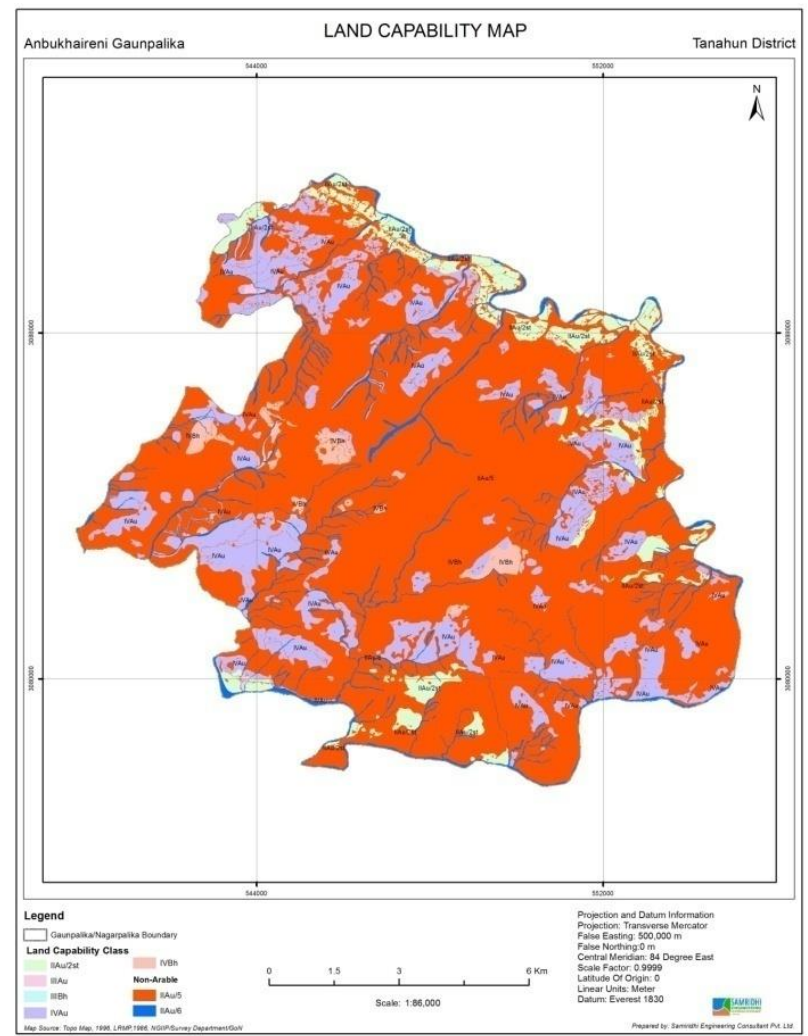

Figure 3: Land capability classification of Aanbu Khaireni, rural municipality of Tanahun district, Nepal.

\subsection{Multi-risk hazard}

Even though, the National Land Use Policy-2013 has focused on the protection of arable lands ensuring food security; multirisk hazards were added as one of essential components of local level land use planning in Nepal only after the devastating earthquake of April 25, 2015 occurred and having exposed us to non-vulnerable secured human settlement in the country. Multi-hazards like fire, landslide, and flood, seismic and industrial were studied adopted respective methodologies mentioned above having safe to erect any physical infrastructure and sustainable local level land use planning to address all contemporary issues on a long term basis particularly for overall goal of planning- land use zoning. All these existing hazard types were separately analyzed and their risk areas were identified on ordinal scale-high, medium \& low. Landslide and flood were found most probable affecting larger areas in hills and terai region respectively. 
Similarly forest fire and settlement fire were also identified most occurred hazards in mountain-hill and terai region respectively particularly in dry season due to lack of awareness and appropriate care. For example, composite risk map of Aanbu Khaireni, Rural Municipality of Tanahun District was shown in Figure 4.

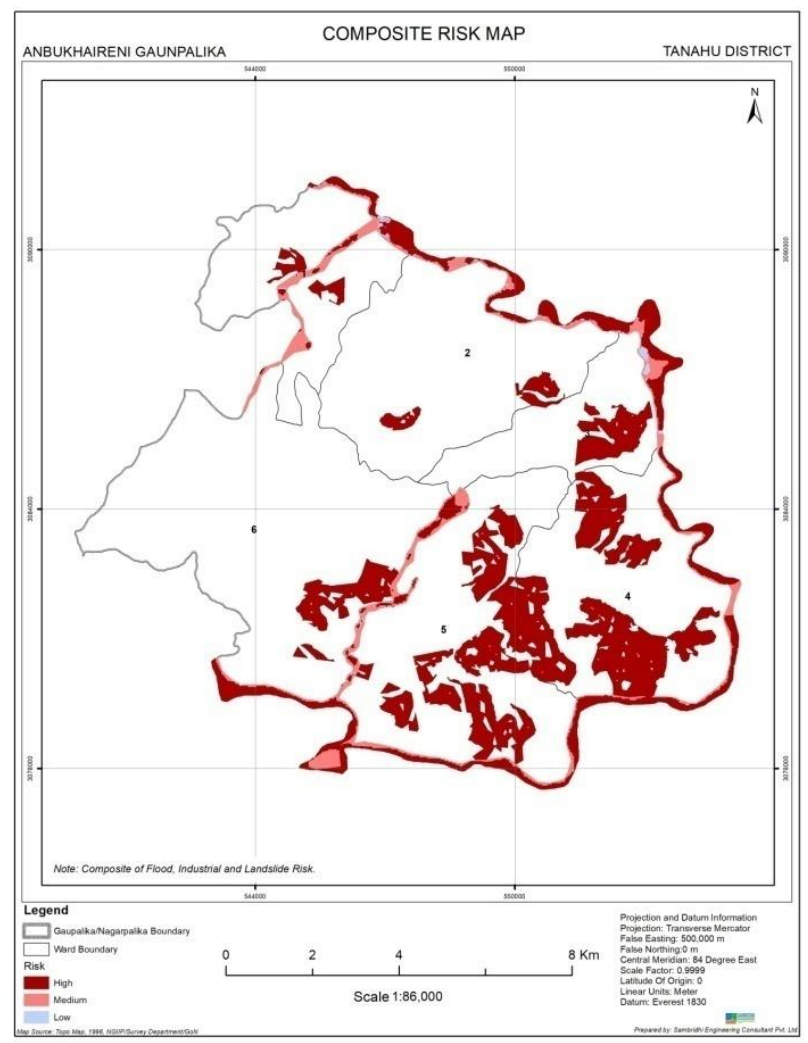

Figure 4: Composite risk map of Aanbu Khaireni, rural municipality of Tanahun district, Nepal.

\subsection{Land Use Zone Classification}

Land use zone classification is the prime goal of local level land use planning in Nepal. Thus it was performed accordingly based on eleven land use zones (Agricultural area, Residential area, Commercial area, Industrial area, Mining and Mineral area, Cultural and Archaeological area, River, Lake and Water bodies area, Excavation area, Forest area, Public Use area and Others).and their sub-zones specified by National Land Use Policy -2015 along with the consideration of guidelines/condition separately mentioned for each zone in the policy. While doing this in geo-spatial domain, present land use, soil, and land capability, multi-hazards and socio-economic condition was heavily taken into consideration while proposing/transforing from one zone to another.

Even though government has policy to keep most of agricultural and forest areas intact but it is almost impossible to retain all areas as some of the newly proposed residential, commercial, industrial and public use areas are proposed on the agricultural land. In such situation, marginal lands were proposed for infrastructure and waste and barren land for forest.

Giving an example, land use zone transformation of Aanbu Khaireni, Rural Municipality of Tanahun District was depicted in Table 4 and its mapping was shown in Figure 5. Table 4 and Figure 5 show how present land use has been proposed to other specified land use based on principle of land necessity, capability and appropriate use.

\begin{tabular}{|c|c|c|c|c|c|c|}
\hline \multirow{2}{*}{$\begin{array}{l}\text { Land us } \\
\text { Categories }\end{array}$} & \multicolumn{2}{|l|}{\begin{tabular}{|l} 
Present \\
Use \\
\end{tabular}} & \multicolumn{2}{|c|}{ Land use zone } & \multirow{2}{*}{$\begin{array}{l}\text { Difference } \\
(\mathrm{Ha})\end{array}$} & \multirow{2}{*}{$\begin{array}{l}\text { Rate of } \\
\text { change } \\
(\%)\end{array}$} \\
\hline & $\begin{array}{l}\text { Area } \\
(\mathrm{Ha})\end{array}$ & Percent & $\begin{array}{l}\text { Area } \\
\mathrm{Ha} \text { ) }\end{array}$ & $\begin{array}{l}\text { Percent } \\
(\%)\end{array}$ & & \\
\hline Agriculture & 3021.08 & 23.60 & 2924.10 & 22.84 & -96.98 & -3.21 \\
\hline Residential & 180.50 & 1.41 & 229.15 & 1.79 & 48.65 & 26.95 \\
\hline Commercial & 23.13 & 0.18 & 39.02 & 0.30 & 15.89 & 68.67 \\
\hline Industrial & 9.62 & 0.08 & 9.76 & 0.08 & 0.14 & 1.49 \\
\hline Forest & 6578.92 & 51.40 & 8569.19 & 66.95 & 1990.26 & 30.25 \\
\hline Public Use & 180.77 & 1.41 & 243.01 & 1.90 & 62.24 & 34.43 \\
\hline $\begin{array}{l}\text { Cultural \& } \\
\text { Archeological }\end{array}$ & 1.66 & 0.01 & 1.50 & 0.01 & -0.16 & -9.79 \\
\hline $\begin{array}{l}\text { Riverine } \\
\text { Lake Area }\end{array}$ & 788.35 & 6.16 & 784.07 & 6.13 & -4.28 & -0.54 \\
\hline Other & 2015.76 & 15.75 & 0.00 & 0.00 & -2015.76 & -100.00 \\
\hline Total & 12799.80 & 100.00 & 12799.80 & 100.00 & 0.00 & \\
\hline
\end{tabular}

. Table 4: Land use zoning of Aanbu Khaireni rural municipality, Tanahun district, Nepal.

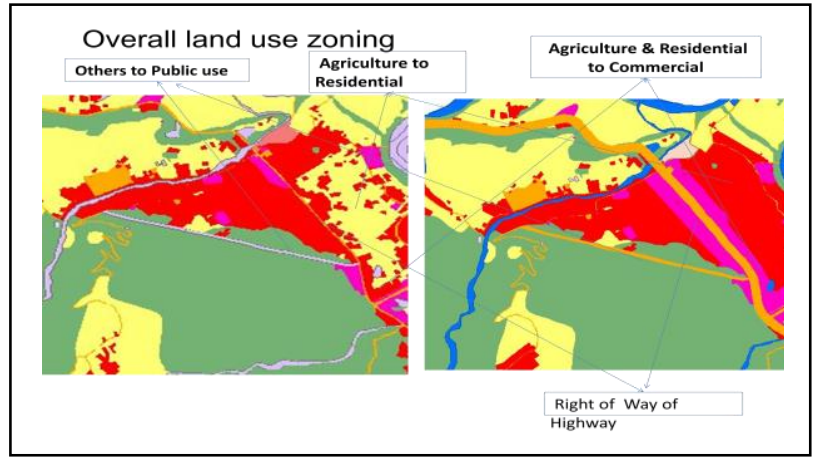

Figure 5: Proposed land use zone of Aanbu Khaireni, rural municipality of Tanahun district, Nepal.

\subsection{Cadastral Superimpose on Land Use Zoning}

Cadastral map is defined as the outlines of the property and the parcel identifier normally are shown on large scale maps which, together with registers, may show for each separate property the nature, size, value and legal rights associated with the parcel (Doley, 1985). It's superimposing on the land use zoning is useful for implementing the National Land Use Policy-2015 at the local level providing the information regarding the proposed land use zone directly in relation with the land owner, its tenant, current land use and the shape and size of the individual parcel. Therefore, the local governments can develop a comprehensive plan on parcel basis guiding a community's land use, conservation of natural resources, economic development, and related public services.

For illustrating the application of geo-spatial technology on preparation of superimposing the cadastral layer on land use zoning, Aanbu Khaireni, Rural Municipality of Tanahun District was put forward as an example and depicted in Table 5 showing parcel magnitude of zoning conversion and cadastral layer was overlaid on world-view-2 satellite image showing in Figure 6 and in the same way it was also superimposed on land use zoning map in Figure 7. 


\begin{tabular}{|c|c|c|c|c|}
\hline $\begin{array}{l}\text { S. } \\
\text { N. }\end{array}$ & Conversion & $\begin{array}{l}\text { No. of } \\
\text { Parcel }\end{array}$ & $\begin{array}{l}\text { Area } \\
\text { (ha) }\end{array}$ & $\begin{array}{l}\text { Percen } \\
\text { tage }\end{array}$ \\
\hline 1 & Agriculture/Agriculture & 21127 & $\begin{array}{r}6375 . \\
23 \\
\end{array}$ & 80.03 \\
\hline 2 & $\begin{array}{l}\text { Riverine \& Lake/Riverine \& } \\
\text { Lake }\end{array}$ & 900 & $\begin{array}{r}354.0 \\
2 \\
\end{array}$ & 4.44 \\
\hline 3 & Forest/Forest & 821 & $\begin{array}{r}334.7 \\
3 \\
\end{array}$ & 4.20 \\
\hline 4 & Residential/Residential & 2756 & $\begin{array}{r}299.5 \\
7 \\
\end{array}$ & 3.76 \\
\hline 5 & Public Use/Public Use & 1558 & $\begin{array}{r}183.0 \\
4\end{array}$ & 2.30 \\
\hline 6 & Agriculture/Residential & 1507 & $\begin{array}{r}138.1 \\
9 \\
\end{array}$ & 1.73 \\
\hline 7 & Others/Forest & 257 & 88.08 & 1.11 \\
\hline 8 & Agriculture/Public Use & 524 & 57.28 & 0.72 \\
\hline 9 & Residential/Commercial & 1034 & 44.17 & 0.55 \\
\hline 10 & Commercial/Commercial & 738 & 23.35 & 0.29 \\
\hline 11 & Industrial/Industrial & 170 & 19.50 & 0.24 \\
\hline 12 & Agriculture/Commercial & 244 & 14.86 & 0.19 \\
\hline 13 & Residential/Public Use & 338 & 10.69 & 0.13 \\
\hline 14 & $\begin{array}{l}\text { Cultural \& } \\
\text { Archeological/Cultural \& } \\
\text { Archeological } \\
\end{array}$ & 4 & 7.27 & 0.09 \\
\hline 15 & Commercial/Public Use & 224 & 5.84 & 0.07 \\
\hline 16 & Forest/Public Use & 60 & 2.68 & 0.03 \\
\hline 17 & Industrial/Public Use & 38 & 2.34 & 0.03 \\
\hline 18 & Riverine \& Lake/Public Use & 66 & 1.95 & 0.02 \\
\hline 19 & Agriculture/Industrial & 6 & 0.99 & 0.01 \\
\hline 20 & Others/Public Use & 10 & 0.97 & 0.01 \\
\hline 21 & $\begin{array}{l}\text { Excavation Area/Excavation } \\
\text { Area }\end{array}$ & 4 & 0.68 & 0.01 \\
\hline 22 & Excavation Area/Public Use & 2 & 0.64 & 0.01 \\
\hline & Grand Total & 32388 & $\begin{array}{r}7966 . \\
05 \\
\end{array}$ & 100.00 \\
\hline
\end{tabular}

Table 5: Land parcels on land use zoning of Aanbu Khaireni rural municipality, Tanahun district, Nepal.

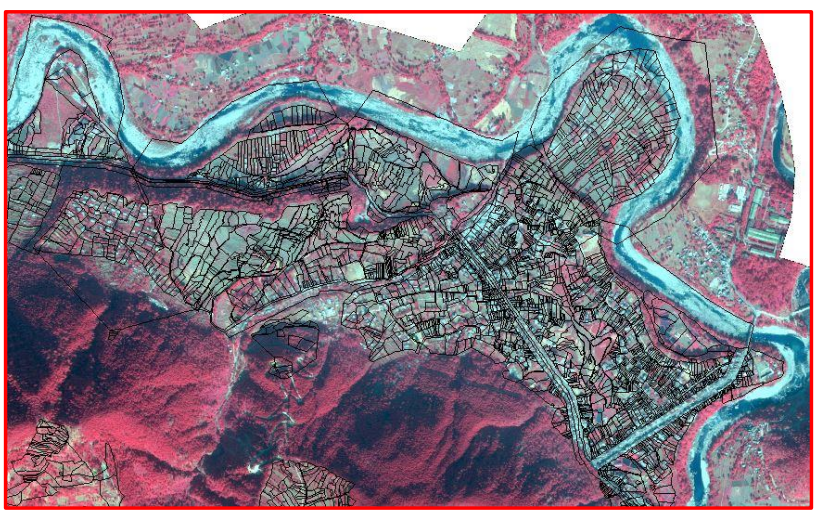

Figure 6: Superimposed of cadastral layer on orthorectified world view-2 of Aanbu Khaireni, rural municipality of Tanahun district, Nepal.
In total 7966 ha of cadastral land parcel currently 7598 ha remains constant and 368 ha of the total cadastral land parcel area were converted from agriculture to residential, commercial, industrial and public use (Table 5).

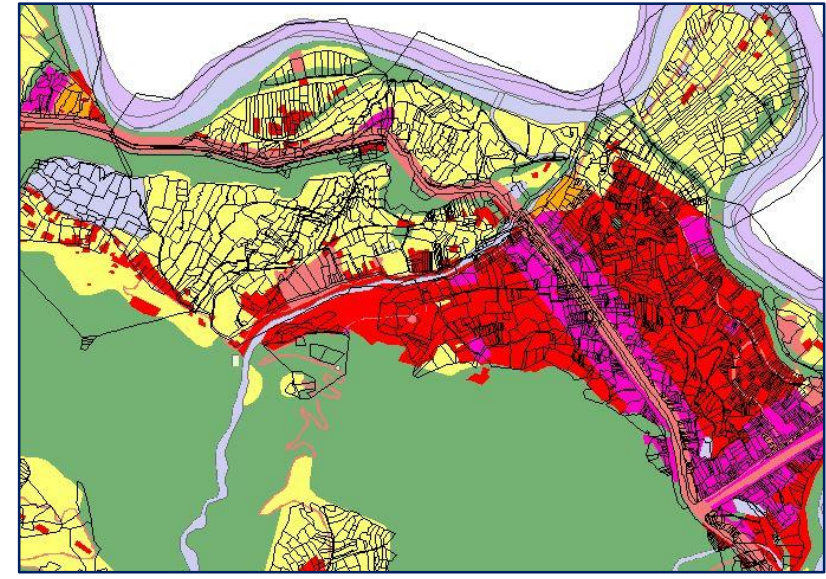

Figure 7: Superimposed of land parcels on land use zoning of Aanbu Khaireni, rural municipality of Tanahun district, Nepal.

\section{CONCLUSIONS}

Even though landsat image and aerial photographs were found used in preparation of land resource maps at regional scale by LRMP, geo-spatial technology incorporating $3 \mathrm{~s}$ as GIS, RS and GPS were first time applied in preparation of resource mapping for local level planning by NLUP at large scale of 1:10000. Geo-spatial technology was found effectively and efficiently used in land resource mapping and its creation of geo-database. Seven components of land resource mapping required for local level land use planning were present land use, soil, land capability multi-hazard, biophysical-socio-economic profile, land use zoning and cadastral superimposed on land use zoning which covered $1404 \mathrm{VDC} /$ Municipalities of terai region of Nepal up to fiscal year 2017/18. The use of high resolution satellite, differential GPS for orthorectification and carrying out detailed soil survey were found outstanding features in this village/municipality level land use planning in Nepal. In all classification like land use, land capability and soil, standard scheme adopted by USDA were employed. In terms of present land use and land use zone, uniformity in numbers and nature/type were not found in National Land Use Policy and it varied from National Land Use Policy-13 to Policy-15 that makes difficult/incompatible to use for entire region. Similarly endopedon of soil should also be studied with their cation exchange capacity and base saturation along with epipedon for entire soil taxonomy study. Al most 50 percent of country's area was covered with this local level land use planning and remaining part should also be completed within two-years and thus basic information/data for every component of land resource mapping should be available for people meaning to use in academic and applied research. National Land Use policy-2015 should be implemented by making Land Use Act for sustainable use and conservation of natural resources in the country. 


\section{REFERENCES}

Bhandari, Ashutosh, 2017 , Land Information System in Nepal GEOSPACE:Annual Geo-ICT Magazine of GES, Volume III pp.14

Bhumichitra ,2000. Nepalma Kitta Napi Karyara BhaviKaryakram (in Nepali). A Report Submitted to the Ministry of Land Reform and Management.

Doley, P. F. 1985. Cadastral Survey within the Commonwealth. London.

GoN/MLRM, 2013..National Land Use Policy-2013, Government of Nepal, Ministry of Land Reform and Management, Singh Darbar, Kathmandu.

GoN/MLRM, 2015. .National Land Use Policy 2015, Government of Nepal, Ministry of Land Reform and Management, Singh Darbar, Kathmandu.

Grose, C. 1999. Land Capability Handbook. Guidelines for the Classification of Agricultural Land in Tasmania

Gurung, H. 2005. Nepal Regional Strategy For Development Working Paper Series No. 3 Nepal Resident Mission
LRMP ,1986. Land Capability Report. Ottawa, Canada: Land Resource Mapping Project, Kenting Earth Sciences Limited.

Malczewski, J. 2000. On the use of weighted linear combination method in GIS: common and best practice approaches. Transactions in GIS 4 (1): 5-22.

NARC , 2013. Methods of Soil Sample Collection and analysis. Soil Science Division, Council of National Agriculture Research, National Agriculture Research Center, Khumaltar, Lalitpur, Nepal.

Srivastava, N.L., 2008. Major Turns in Planned Development of Nepal. The Nepalese Journal of Business Studies Vol.V No. 1 :pp, 1.

Store, R. and J. Kangas 2001. Integrating spatial multi-criteria evaluation and expert knowledge for GIS-based habitat suitability modelling. Landscape and urban planning 55(2): pp. 79-93.

USDA ,2017. Soil Survey Manual. United States Department of Agriculture.

USDA, 2010. Key to Soil Taxonomy 11th ed. USDA, Washington, DC. 